\title{
12. PETROLOGY AND DIAGENESIS OF SANDSTONES, DEEP SEA DRILLING PROJECT SITE 445, DAITO RIDGE
}

\author{
George deVries Klein, Richard L. McConville, Janet M. Harris, and C. K. Steffensen, \\ University of Illinois at Urbana-Champaign
}

\section{INTRODUCTION}

The sandstone succession in the lower 240 meters of DSDP Site 445, on the Daito Ridge (Figure 1), provided an opportunity to evaluate the effect of burial diagenesis of sandstones in a deep hole in a tectonic environment (remnant arc) characterized by a history of high heat flow. This report provides preliminary data concerning the petrology and diagenesis of these sandstones and records diagenetic changes which have occurred with increasing depth of burial. Depths from which our samples were obtained are shown in Tables 1 and 2.

Methods used for this study included grain-size analysis (measured from thin sections using the method of Friedman, 1958), polarizing microscopy, X-ray diffraction, and scanning electron microscopy. A JEOL scanning electron microscope fitted with an energydispersive-X-ray detector was used for obtaining qualitative chemical data on certain minerals to aid in identification.

\section{GRAIN-SIZE DISTRIBUTION}

Table 1 summarizes the grain-size distributions determined from thin-section analysis (after Friedman, 1958). Most samples are unimodal, except for conglomeratic sandstones and those sandstones containing a relatively large volume of clasts of the larger foraminifer Nummulites boninensis. Median diameters range from 0.125 to $2.0 \mathrm{~mm}$ in sandstones; higher median diameters occur in two samples of conglomeratic sandstone.

\section{SANDSTONE MINERALOGY AND PETROLOGY}

Table 2 summarizes modal analyses of 27 samples which were used in this study. A total of 320 points were counted for each slide. Detrital grains include recognizable volcanic-rock fragments (plagioclase phyric basalt, aphyric basalt, andesite, and microdolerite), plagioclase, limestone rock fragments ("lumps" of some classifications), fragments of the larger foraminifer Nummulites boninensis, other foraminifers, augite, olivine, clinopyroxene, and accessory chert.

Devitrified volcanic glass was encountered in the upper part of the section. Scattered fragments of siltstone were encountered in one sample, and oolites were observed in another. Fragments of pelecypod shells were found in two samples.

These sandstones were poorly cemented in the upper part of the sandstone section, being cemented only by a rim cement consisting of smectite (Figures 2 and 3 ) and, in one instance, mordenite (Figure 4). Smectite was identified by optical mineralogy (Figure 2), scanning electron microscopy (Figure 5), energy-dispersive-X-ray analysis (Figure 6), and X-ray diffraction. Table 3 summarizes the major-element composition of smectite and mordenite from selected samples. These relative abundances of elements are consistent with the morphological, X-ray, and optical identifications. Mordenite was observed in one specimen (Figure 4) and identified by the same methods; the relative abundances of elements are consistent with the known chemical composition of this mineral (Deer et al., 1966).

At greater depths, the sandstones were cemented also by clear sparry calcite (Figures 7 through 12). Authigenic components include calcite replacing both volcanicrock fragments and plagioclase (Figure 13) and chert replacing volcanic-rock fragments (Figures 14 and 15), plagioclase, and calcite.

\section{PROVENANCE AND DIAGENESIS}

\section{Provenance}

The grain components of the sandstones can be grouped into two classes: carbonate shelly debris, and volcaniclastic components including volcanic rock fragments and highly refractory minerals (augite, pyroxene, olivine). The position of Site 445 in a small basin on the flank of the Daito Ridge, a remnant arc, suggests that the arc was the source of these components. Dredge hauls in the Daito Ridge area by Mizuno et al. (1975) and Shiki et al. (1974) indicate that the ridge is composed of volcanic rocks of the type represented in the volcaniclastic components, which confirms this interpretation.

The carbonate fraction is dominantly of shallowwater derivation. The fragments of the giant shallowwater foraminifer Nummulites boninensis indicate transfer of material from shallow water, presumably a coastal strip along the former arc. Other carbonate components also clearly indicate derivation from shallow water along the former arc; these include fragments of pelecypods, micritic and bioclastic limestone, and oolites. These materials presumably were transported by turbidity currents; many of our sandstone samples were obtained from graded intervals which show partial or complete Bouma sequences. (See Site 445 report and other sedimentological studies in this volume.)

In summary, the sandstones at Site $\mathbf{4 4 5}$ were derived from an active island arc (now a remnant arc, Daito Ridge). 


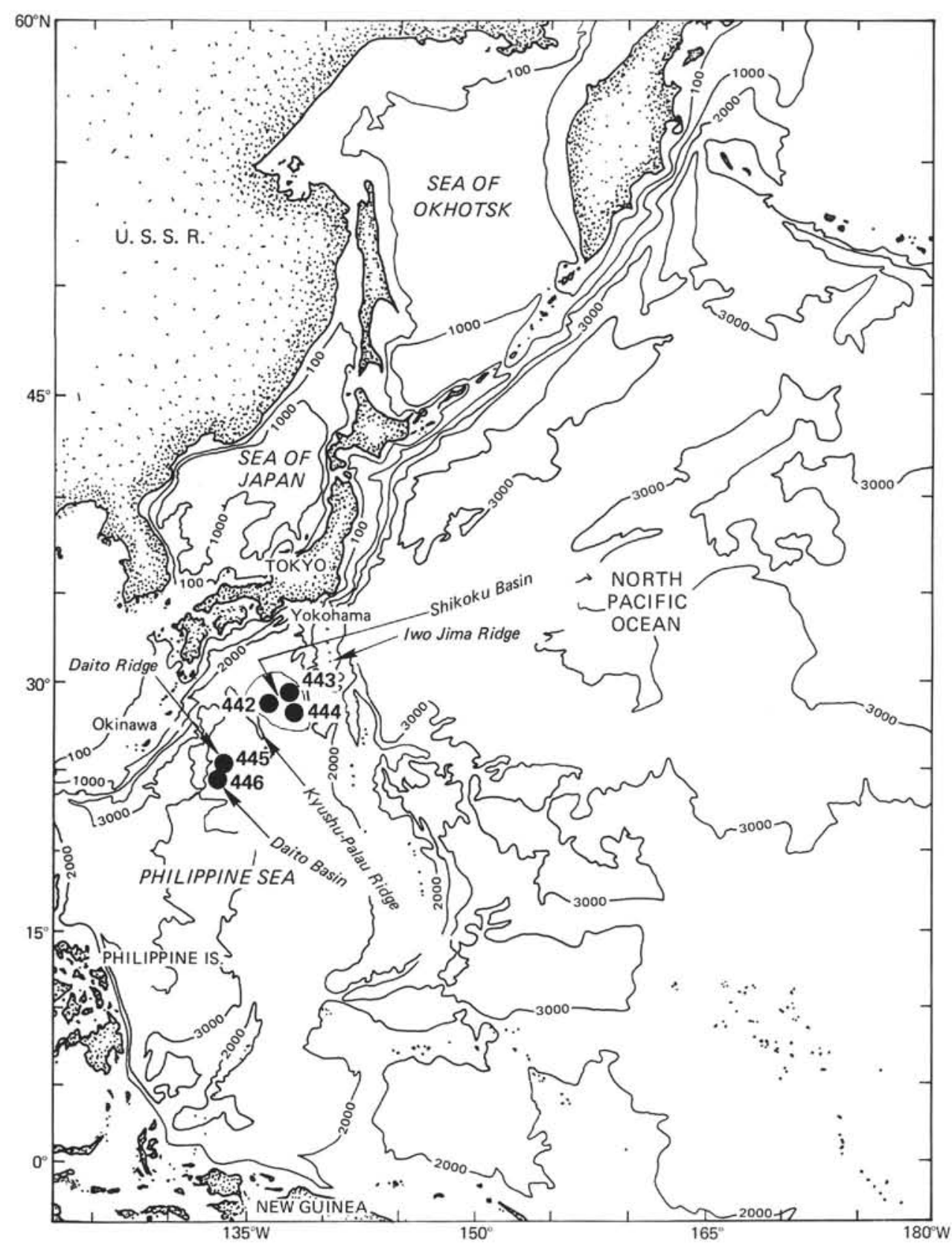

Figure 1. Location of DSDP Site 445.

\section{Diagenesis}

Examination of the authigenic mineral components and cements (Table 2) indicates that diagenetic changes are related to depth of burial. Thin section and SEM study revealed that the earliest authigenic mineral phase is smectite, found as rim cement (Figures 2, 7-12) and mordenite (Figure 4). Smectite rim cementation is first observed in sandstone from a sub-bottom depth of about 645 meters. At a sub-bottom depth of 700 meters, two additional changes are observed: recrystallization of carbonate grains, and the development of pressurewelded, embayed grain contacts in limestone fragments. At a depth of 735 meters, sparry-calcite pore-filling cement, completely filling original pore space, is first ob- served; this change persists downhole (Figures 7-12). At 745 meters, calcite has replaced both plagioclase (Figure 13) and volcanic rock fragments; this replacement is observed also in one or two grains from higher samples. At 750 meters, chertification of volcanic-rock fragments becomes dominant (Figures 14, 15). Below 810 meters, recrystallization of calcite cement is common.

These depth-dependent diagenetic changes are summarized in Figure 16.

\section{PRELIMINARY CONCLUSIONS}

The sandstones in the basal portion of the sequence at Site $\mathbf{4 4 5}$ consist of dominant grain components of andesitic volcaniclastic fragments and of fragments of lar- 
TABLE 1

Grain-Size Distribution (\%) by Phi-Unit Classes, Determined from Thin Sections of Sandstones, Site 445 (100 Points Counted)

\begin{tabular}{|c|c|c|c|c|c|c|c|c|c|c|c|c|c|c|c|c|c|}
\hline \multirow{2}{*}{$\begin{array}{c}\text { Sample } \\
\text { (interval in } \mathrm{cm} \text { ) }\end{array}$} & \multirow{2}{*}{$\begin{array}{l}\text { Sub-bottom } \\
\text { Depth } \\
\text { (m) }\end{array}$} & \multicolumn{15}{|c|}{$\phi$ Units } & \multirow{2}{*}{$\begin{array}{c}\phi 50 \\
\text { (median } \\
\text { diameter) }\end{array}$} \\
\hline & & -1.75 & -1.25 & -0.75 & -0.25 & +0.25 & 0.75 & 1.25 & 1.75 & 2.25 & 2.75 & 3.25 & 3.75 & 4.25 & 4.75 & $>4.75$ & \\
\hline $445-69-2,70-72$ & 647.20 & 20 & 22 & 25 & 18 & 5 & 4 & 4 & - & 1 & 1 & - & - & - & - & - & -1.00 \\
\hline $2,143-149$ & 647.93 & - & - & 2 & 2 & 3 & 11 & 16 & 21 & 26 & 12 & 5 & 1 & 1 & - & - & +1.64 \\
\hline $71-1,90-91$ & 664.90 & - & 1 & 5 & 19 & 13 & 25 & 17 & 12 & 6 & 2 & - & - & - & - & - & +0.40 \\
\hline $2,37-40$ & 665.87 & - & - & - & - & - & - & - & - & 4 & 5 & 11 & 9 & 15 & 19 & 37 & +2.95 \\
\hline $75-6,97-100$ & 710.47 & - & - & - & - & 3 & 6 & 20 & 17 & 24 & 16 & 10 & 4 & - & - & - & +1.95 \\
\hline $76-1,23-28$ & 711.73 & - & - & - & 1 & 1 & 10 & 27 & 22 & 21 & 5 & 8 & 4 & - & 1 & - & +1.50 \\
\hline $1,122-125$ & 712.72 & - & - & - & 3 & 8 & 11 & 19 & 25 & 25 & 6 & 3 & - & - & - & - & +1.45 \\
\hline $3,23-25$ & 714.73 & - & - & 1 & - & 3 & 2 & 2 & 10 & 15 & 19 & 23 & 16 & 6 & 3 & - & +2.80 \\
\hline $77-4,99-104$ & 726.49 & - & 3 & 1 & 4 & 18 & 13 & 20 & 21 & 15 & 5 & - & - & - & - & - & +1.33 \\
\hline $78-3,58-63$ & 734.08 & 5 & 1 & - & 5 & 9 & 20 & 21 & 16 & 14 & 8 & - & 1 & - & - & - & +1.35 \\
\hline $5,0-4$ & 736.50 & 11 & 15 & 26 & 18 & 11 & 10 & 5 & 2 & 1 & 1 & - & - & - & - & - & -0.79 \\
\hline $79-2,143-148$ & 743.93 & - & - & 4 & 2 & 7 & 13 & 21 & 10 & 19 & 11 & 9 & 4 & - & - & - & +1.65 \\
\hline $84-2,124-126$ & 790.24 & - & - & 3 & 4 & 6 & 8 & 17 & 15 & 23 & 14 & 8 & 2 & - & - & - & +2.05 \\
\hline $85-1,18-20$ & 797.18 & - & - & - & 8 & 20 & 18 & 25 & 12 & 13 & 3 & - & - & 1 & - & - & +1.15 \\
\hline $86-1,92-94$ & 797.92 & - & - & - & - & 11 & 18 & 24 & 9 & 22 & 9 & 5 & 1 & 1 & - & - & +1.25 \\
\hline $4,73-75$ & 811.73 & - & - & - & - & - & 2 & 11 & 16 & 33 & 24 & 7 & 5 & 2 & - & - & +2.15 \\
\hline $88-2,24-26$ & 827.24 & - & - & 19 & 20 & 26 & 10 & 10 & 5 & 5 & 3 & 2 & - & - & - & - & -0.20 \\
\hline $89-1,131-142$ & 836.31 & 6 & 1 & 3 & 7 & 8 & 14 & 26 & 11 & 21 & 2 & 1 & - & - & - & - & +0.85 \\
\hline $90-2,11-14$ & 846.11 & - & 5 & 9 & 9 & 15 & 16 & 30 & 8 & 5 & 3 & - & - & - & - & - & +0.63 \\
\hline $2,17-21$ & 846.17 & 4 & 16 & 19 & 7 & 8 & 14 & 22 & 5 & 5 & - & - & - & - & - & - & -0.10 \\
\hline $2,22-26$ & 846.22 & - & 3 & 1 & 7 & 12 & 17 & 14 & 11 & 13 & 6 & 11 & 2 & - & 1 & 2 & +1.10 \\
\hline $91-2,64-70$ & 856.14 & - & - & 8 & 13 & 18 & 15 & 15 & 11 & 10 & 4 & 3 & 2 & 1 & - & - & +0.60 \\
\hline $4,84-88$ & 859.34 & 64 & 2 & 8 & 5 & 4 & 4 & 4 & 3 & 4 & 2 & - & - & - & - & - & -2.00 \\
\hline $92-3,40-48$ & 866.90 & - & - & - & 2 & 9 & 18 & 18 & 24 & 23 & 5 & 1 & - & - & - & - & +1.33 \\
\hline $93-4,127-132$ & 878.77 & - & - & - & 1 & 3 & 13 & 20 & 31 & 19 & 10 & 3 & - & - & - & - & +1.55 \\
\hline $94-2,78-82$ & 884.78 & - & 2 & 6 & 4 & 10 & 15 & 25 & 7 & 16 & 10 & 4 & 1 & - & - & - & +1.10 \\
\hline $4,132-134$ & 888.32 & 58 & 19 & - & 7 & 6 & 5 & 3 & 2 & - & - & - & - & - & - & - & -1.50 \\
\hline
\end{tabular}

ger foraminifers. These sandstones were derived from an island-arc source, and a shallow-water setting. Transport of this sediment was by gravity processes, mostly turbidity currents, debris flow, and slumping.

Down-hole, progressive changes occur in the appearance of authigenic components. These include initial rim cementation of grains by smectite and mordenite, subsequent pressure welding and pore-space reduction, and later pore-filling by sparry-calcite cement. Down-hole, carbonate materials were observed to recrystallize with depth. Carbonate minerals replace plagioclase and volcaniclastic rock fragments with increasing depth. The last replacement event to occur that is also depth-dependent is the chertification of recognizable rock fragments; this replacement increases in frequency down-hole.

These vertical changes are clearly a function of depth of burial. The effect of high regional heat-flow values could not be evaluated, because of lack of temperature data from the drill site.

\section{ACKNOWLEDGMENTS}

Financial support for the laboratory phase of this study came from a grant awarded by the University of Illinois
Research Board. Division of labor on this project is as follows: Grain-size study was completed by Harris and Steffensen; scanning electron microscopy and energy-dispersive-X-ray analysis was completed by McConville; and petrology and diagenesis were completed by Klein. D. D. Ebert kindly made the X-ray identification of the rim-cementing minerals. E. D. Pittman and F. G. Ethridge reviewed an earlier manuscript version of this paper.

\section{REFERENCES}

Deer, W. A., Howie, R. A., and Zussman, J., 1966. An Introduction to the Rock-Forming Minerals: London (Longman).

Friedman, G. M., 1958. Determination of sieve-size distribution from thin-section data for sedimentary petrological studies. J. Geol., 66, 394-416.

Mizuno, A., Okuda, Y., Tamaki, K., Kinoshita, Y., Nohara, M., Yuasa, M., Nakajima, M., Murakami, S., and Ishibaski, K., 1975. Marine geology and geological history of the Daito Ridge area, northwestern Philippine Sea. Mar. Sci., 7, 484-491, 543-548.

Shiki, T., Aoki, H., Suzuki, H., Masashino, M., and Okuda, Y., 1974. Geological and petrographical results of the GDP-8 cruise in the Philippine Sea. Mar. Sci., 6, 51-55. 
TABLE 2

Modal Analyses of Sandstones, Hole 445 ( $\%$, based on 320 points)

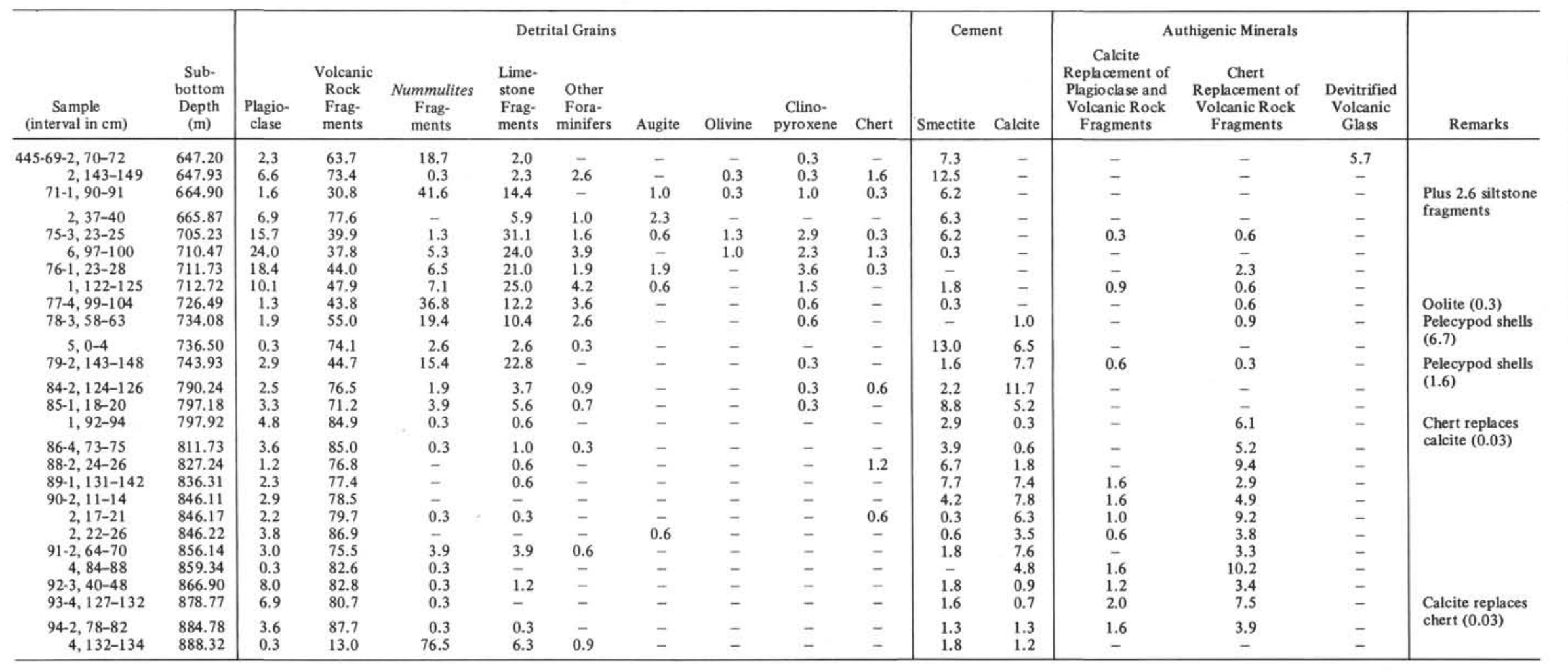




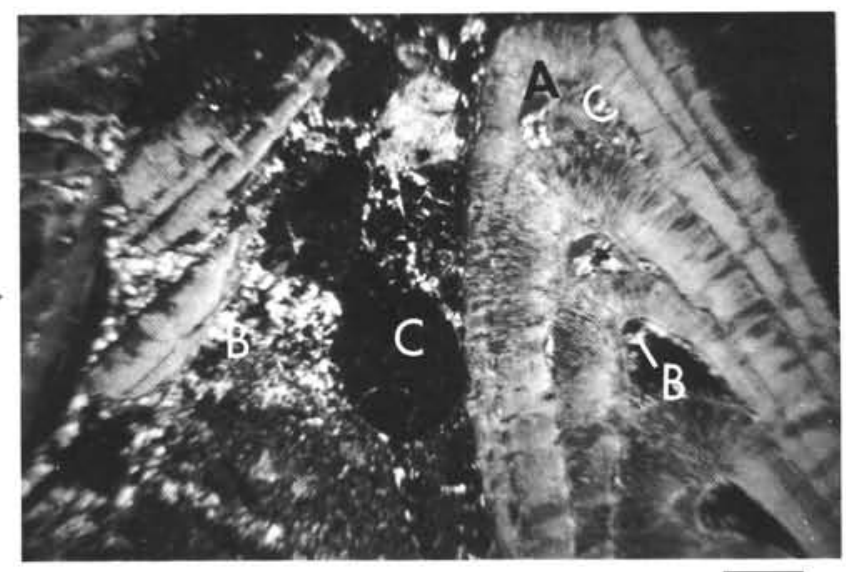

Figure 2. Photomicrograph (crossed nicols) showing fragment of Nummulites boninensis $(A)$ with rim cement of smectite around pore edges. (B) volcaniclastic grains $(C)$ also are rim cemented with smectite. Bar scale is 0.5 mm long. Sample 445-69-2, 70-72 cm.

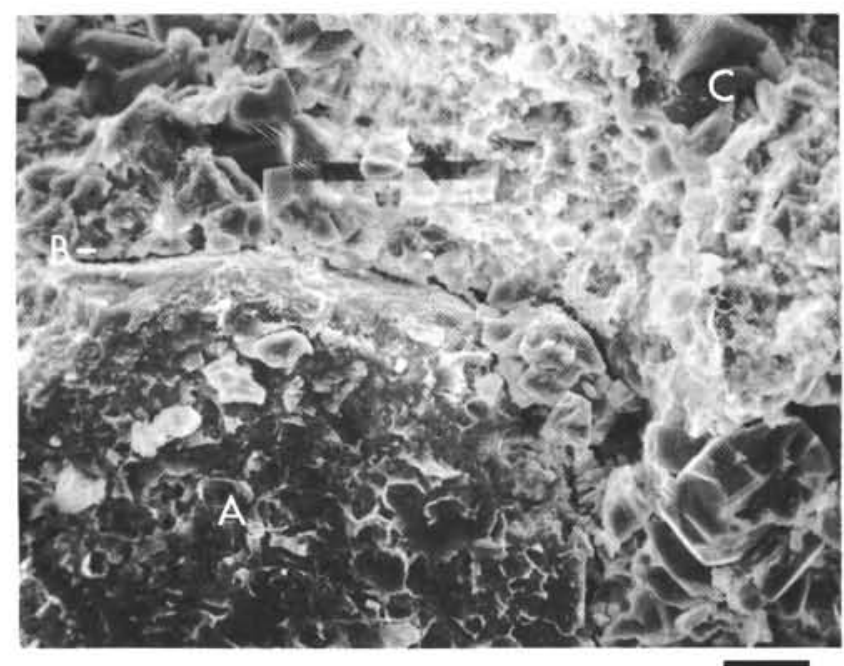

Figure 3. Scanning electron photomicrograph showing volcaniclastic grain $(A)$, with rim cement of smectite $(B)$, and calcite pore fill (C). Bar scale is $25 \mu \mathrm{m}$. Sample 445-84-2, $124-126 \mathrm{~cm}$.

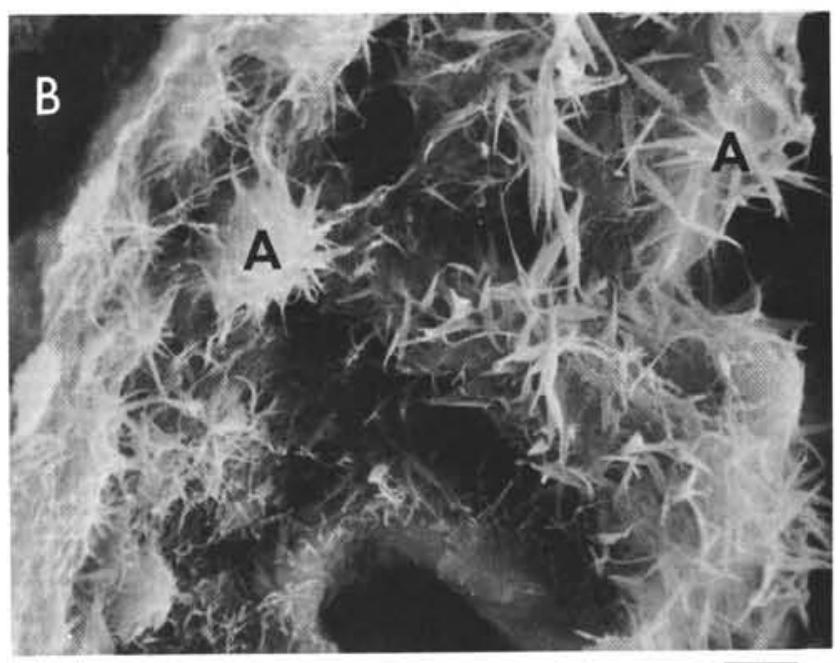

Figure 4. Scanning electron photomicrograph of mordenite rim cement $(A)$ on volcaniclastic grain $(B)$. Bar scale is $5 \mu \mathrm{m}$. Sample 445-69-2, 143-149 cm.

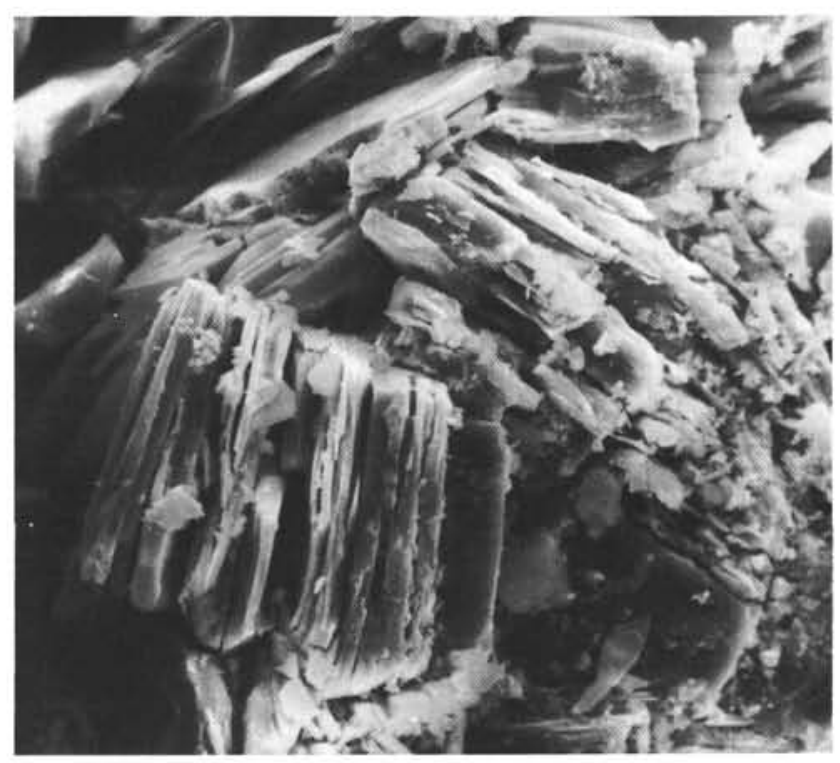

Figure 5. Scanning electron photomicrograph of smectite. Bar scale is $10 \mu \mathrm{m}$. Sample 445-69-2, 70-72 cm. 


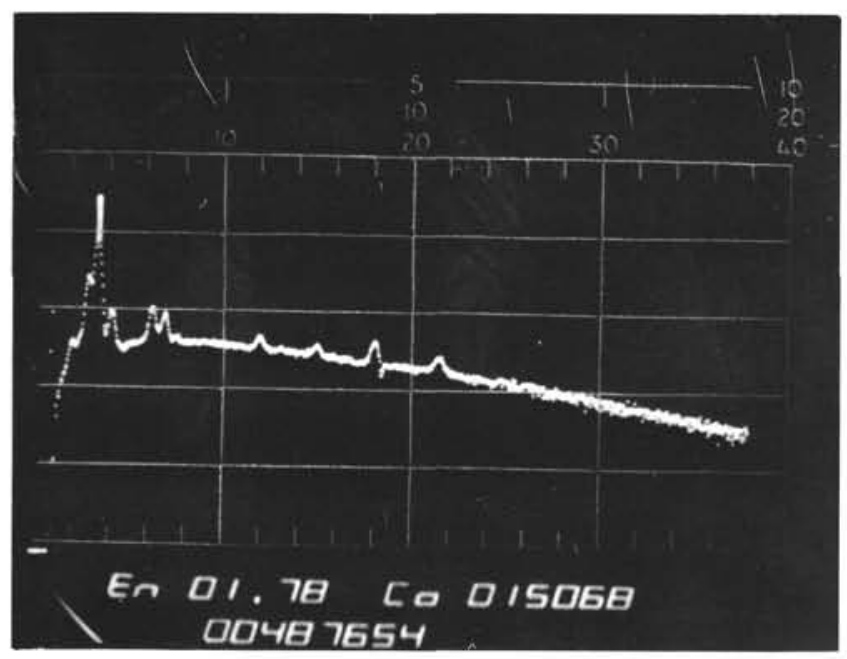

Figure 6. X-ray spectrum of smectite shown in Figure 5. Major peaks are silicon, potassium, and calcium.

TABLE 3

Chemical Elements (in order of decreasing abundance) Determined from Energy-Dispersive-X-ray Analysis of Specific Minerals

\begin{tabular}{lll}
\hline $\begin{array}{c}\text { Sample } \\
\text { (interval in cm) }\end{array}$ & \multicolumn{1}{c}{ Mineral } & \multicolumn{1}{c}{ Elements } \\
\hline $445-69-2,70-72$ & Smectite & Si, Fe, Ca, K, A1, Ti \\
$445-69-2,143-149$ & Mordenite & $\mathrm{Si}, \mathrm{K}, \mathrm{Ca}, \mathrm{Al}$ \\
$445-84-2,124-126$ & Smectite & $\mathrm{Al}, \mathrm{Ca}, \mathrm{Si}, \mathrm{Fe}, \mathrm{K}$ \\
$445-93-4,127-132$ & Smectite & $\mathrm{Si}, \mathrm{Al}, \mathrm{Fe}, \mathrm{Ca}, \mathrm{K}$ \\
\hline
\end{tabular}

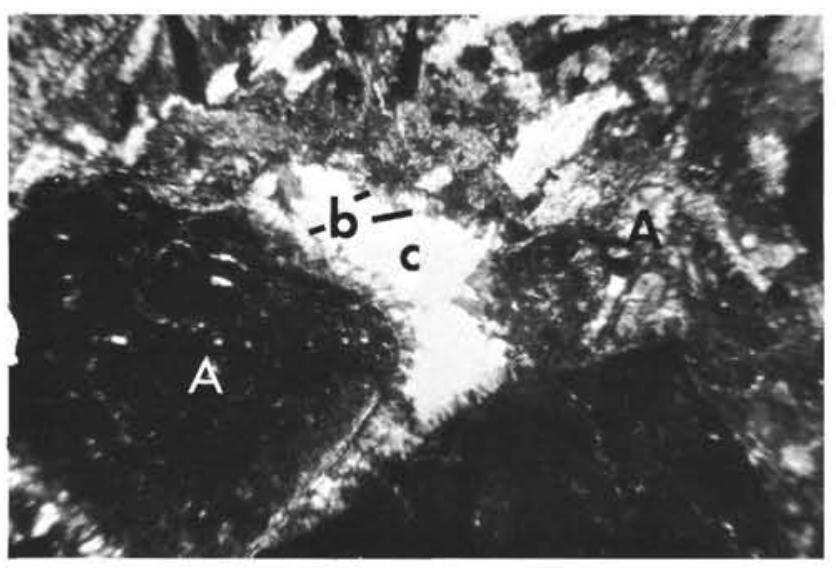

Figure 7. Photomicrograph of volcaniclastic sandstone (A) with rim cement of smectite (B) and pore-filling cement of calcite (C). Bar scale is $0.1 \mathrm{~mm}$. Crossed nicols. Sample 445-78-5, 0-4 cm.

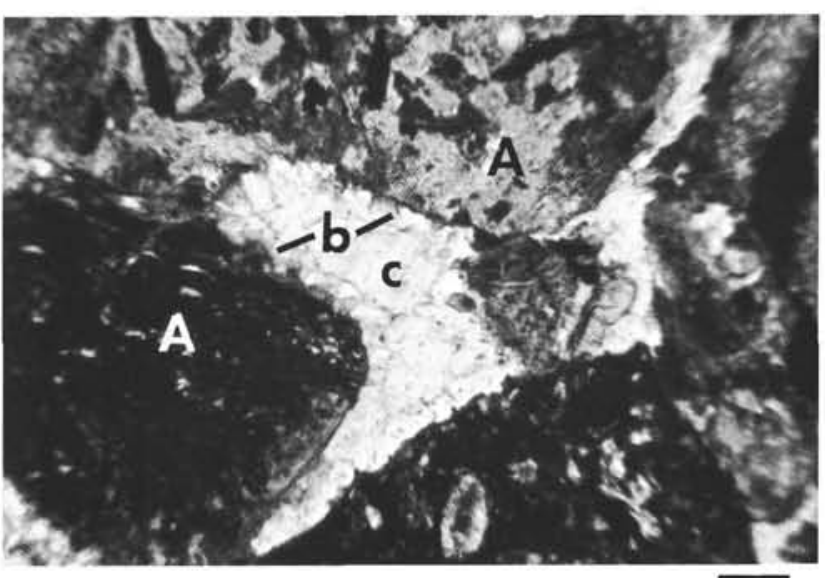

Figure 8. Same as Figure 7, plane light.

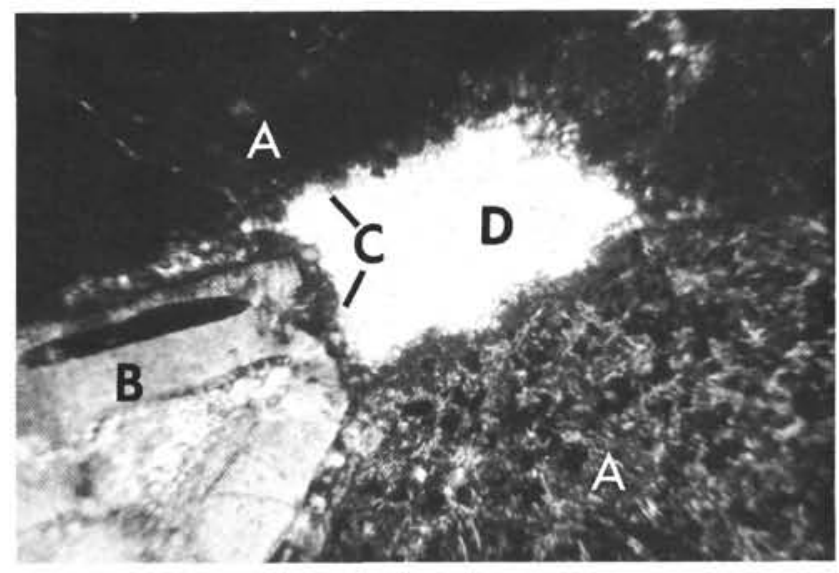

Figure 9. Photomicrograph of volcaniclastic sandstone $(A)$, containing Nummulites fragments $(B)$, with rim cement of smectite $(C)$, and pore-fill cement of calcite (D). Crossed nicols. Bar scale is $0.1 \mathrm{~mm}$. Sample 445-78-5, 0-4 cm.

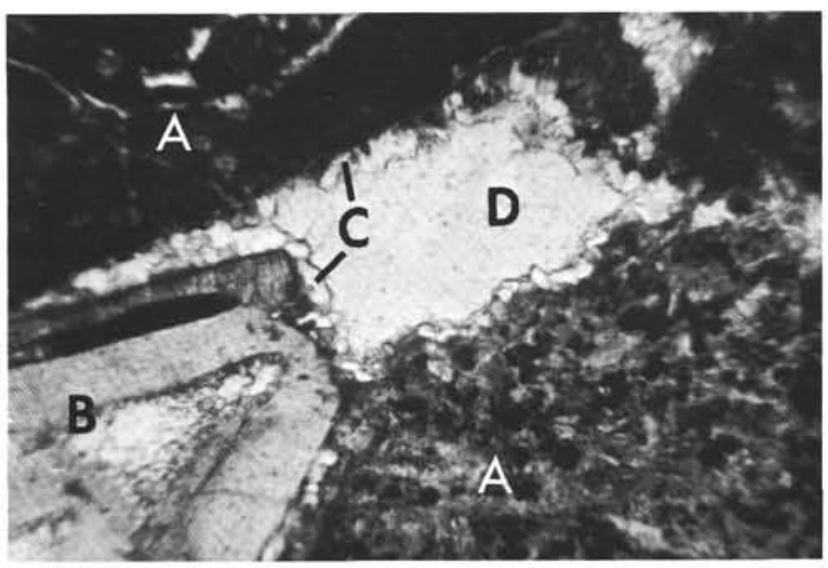

Figure 10. Same as Figure 9, plane light. 


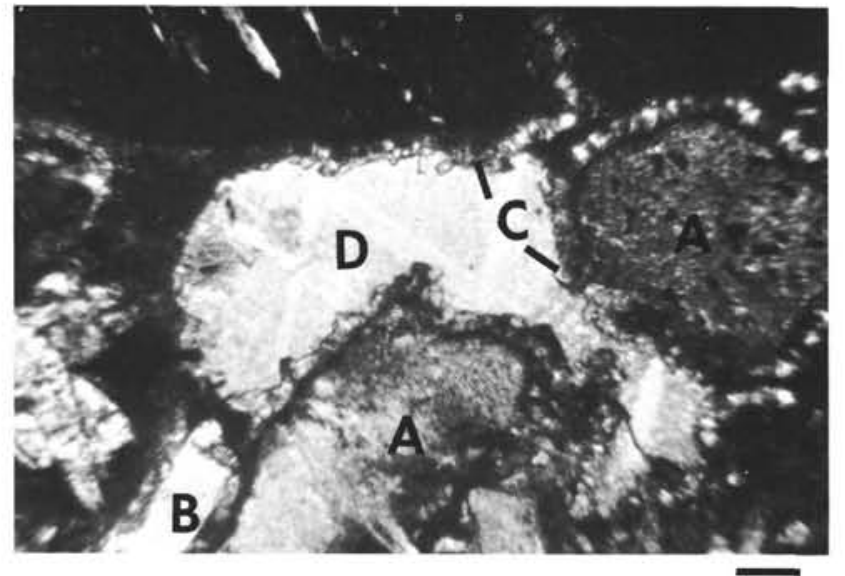

Figure 11. Photomicrograph of volcaniclastic sandstone, showing volcanic-rock fragments $(A)$, plagioclase $(B)$, rim cement of smectite $(C)$ and pore filling cement of calcite (D). Crossed nicols. Bar scale is 0.1 $\mathrm{mm}$. Sample 445-78-5, 0-4 cm.

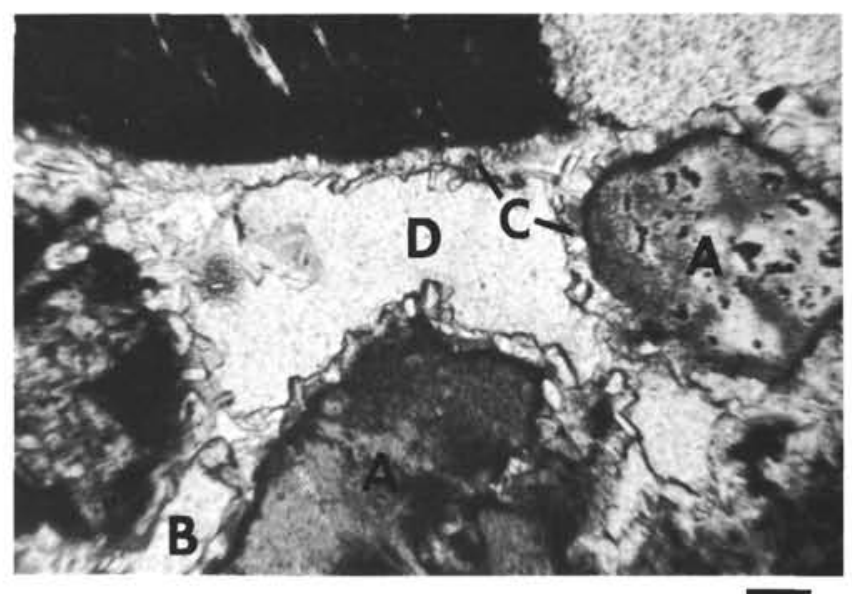

Figure 12. Same as Figure 11, plane light.

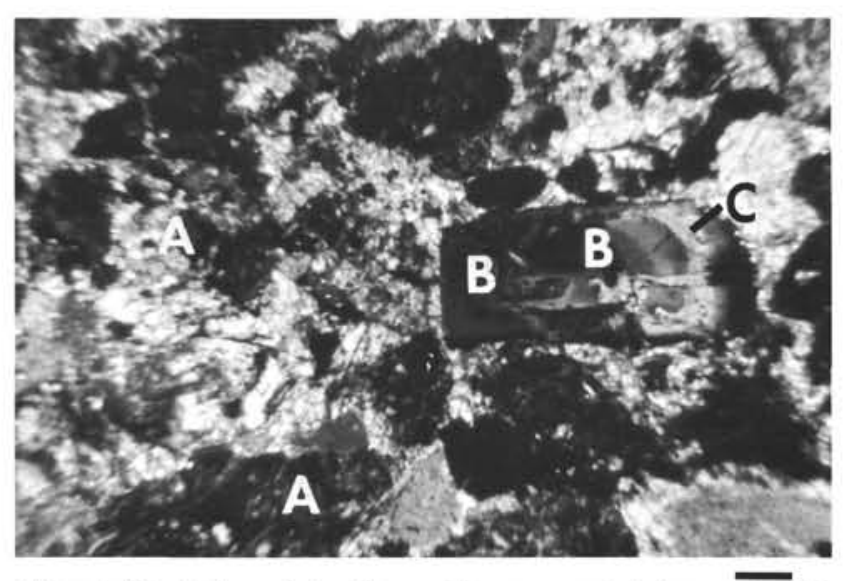

Figure 13. Volcaniclastic sandstone containing volcanicrock fragments $(A)$, plagioclase $(B)$, and calcite replacement of plagioclase (C). Crossed nicols. Bar scale is $0.1 \mathrm{~mm}$. Sample 445-84-2, 124-126 cm.

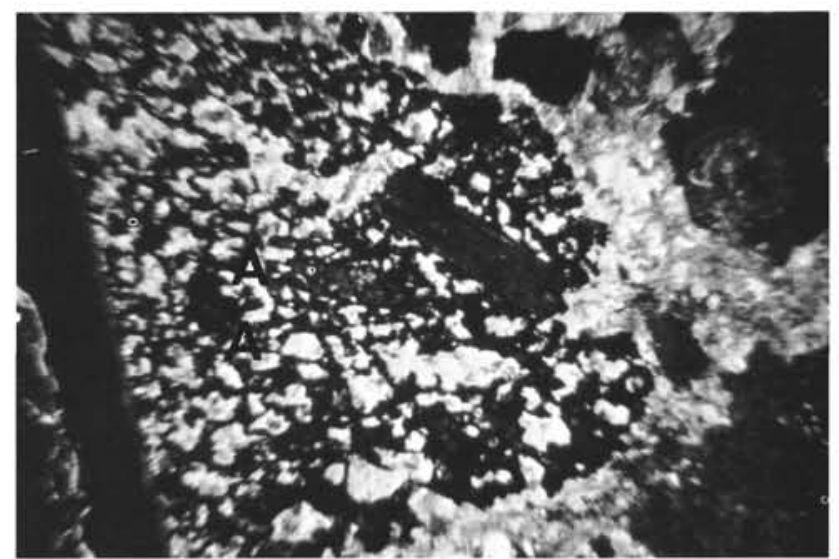

Figure 14. Photomicrograph of volcaniclastic sandstone showing volcaniclastic rock fragment replaced by chalcedony (A). Crossed nicols. Bar scale is $0.5 \mathrm{~mm}$. Sample 445-91-4, 84-88 cm.

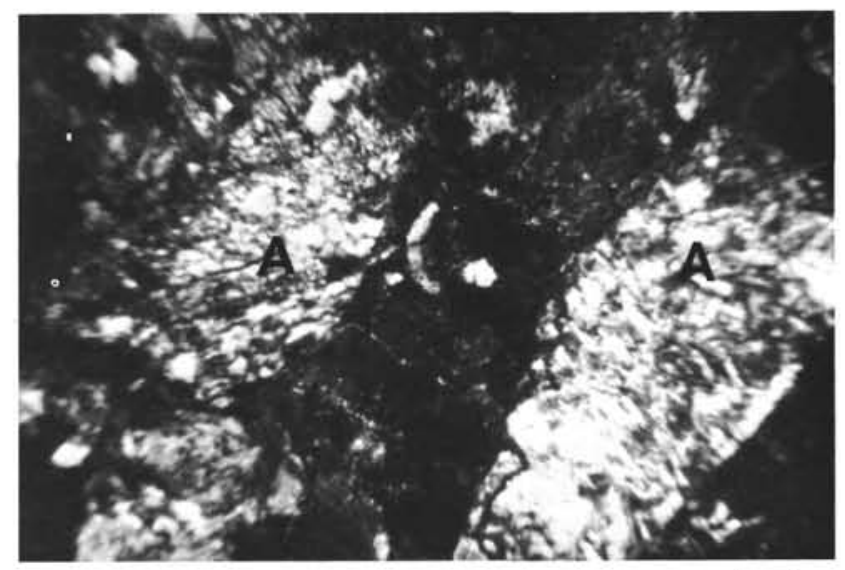

Figure 15. Photomicrograph of volcaniclastic sandstone showing volcaniclastic grains totally replaced by chalcedony and chert (A). Crossed nicols. Bar scale is $0.1 \mathrm{~mm}$. Sample 445-93-4, 127-132 cm. 


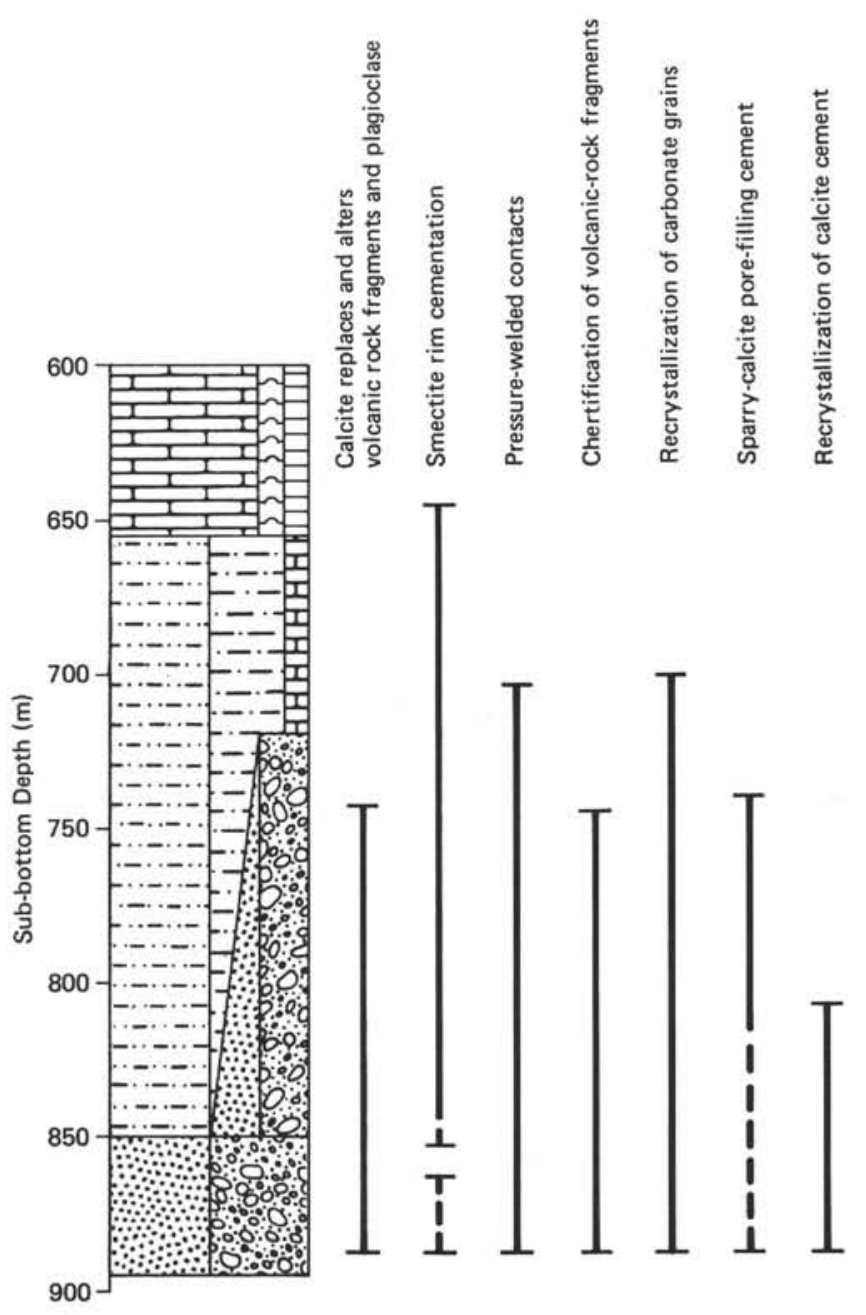

Figure 16. Depth distribution of lithologies and diagenetic changes in sandstones at Site 445. 